\title{
Individual Cognitive Effort and Cognitive Transition during Organization Development
}

Philip J. Maxton Ph.D.

U. of Pretoria

South Africa
Gervase R. Bushe

Simon Fraser U.

Canada

Journal of Applied Behavioral Science 2018: 54, in press

\begin{abstract}
How do personal mindsets change during an organization development intervention and how are these transitions associated with the intervention characteristics? In a qualitative theorydriven case study based in South Africa, the transitions of six individuals during an appreciative inquiry were scrutinized longitudinally for first-order and second-order changes. Five individuals showed first-order changes and two showed second-order changes. The engaging and emergent characteristic of the intervention explained the majority of these cognitive transitions. A third type of change in mindset emerged in four of the cases: the development of an appreciative stance, which we classify as a form of cognitive effort rather than a cognitive transition. We conclude that interventions focusing on positivity may lead to participants developing an appreciative stance, but successful organization development might not occur without sufficient engagement in an emergent process. We provide some guidelines for practitioners for conducting an engaging emergent change process.
\end{abstract}

\section{Keywords}

Transition, First-order Change, Second-order Change, Schemata, Dialogic Organization Development, Dialogic OD, Appreciative Inquiry. 
The extent to which organizational change can be planned or managed has become increasingly contentious (By, 2005) and outcomes of organizational change efforts are often different from those initially planned (Balogun and Johnson, 2005; Tsoukas and Chia, 2002). Tsoukas and Chia (2002) argue that if organization is as much an outcome of change as a topdown, planned institution then it is important to improve understanding of the cognitive processes at the level of the individual during organizational change which influence these change trajectories. Hence, rather than focus on synoptic - or summary-accounts of organizational change, the research here focuses on performative accounts which provide insights into the change process at the level of the individual. A focus at the level of the individual in organizational change research is in line with the growing consensus that change recipients' reactions to change have a key role in determining the outcome of the change process (Bartunek, Balogun, \& Do, 2011; Oreg, Vakola, \& Armenakis, 2011).

During an organizational change intervention, the mindsets of transitioning individual participants may change in various ways and these ways may be influenced by certain characteristics of the intervention. This study aims to provide a better understanding of these types of mindset changes and their antecedents in order to improve theoretical insight into organizational change and to enable organization development practitioners to design and facilitate more effective interventions.

The research adopts the terminology introduced by Bridges (1986) that change and transition are two parallel dynamics: change being external to the individual as distinct from transition which is internal to the individual. We will refer to cognitive transition as changes in schemata at the level of the individual. Bartlett (1932) first described schemata as hypothetical mental structures controlling attention and the subsequent reconstruction of memory. In a review of managerial and organizational cognitions, Walsh (1995) explains that individuals create knowledge structures to assist with information processing and, although such knowledge structures are sometimes referred to by terms such as worldview and frames of reference the term schema is prominent. Drawing on Bruning's $(1994$, p. 8) work in the field of cognitive psychology as applied to education, we will adopt the definition of schemata as "hypothesized mental frameworks that give organization to incoming information, that guide attention and perception, and that limit or enhance the learners' ability to understand information".

Schema related organizational change research has examined the role that collective schema play in interpreting change which is external to an organization (e.g., Greve \& Taylor, 2000; Nigam, Huising, \& Golden, 2016). It has also looked at the role schemata play 
in the acceptance of planned internal organizational change at the collective level (e.g., Bess, 2015; Konlechner, Müller, Güttel, Koprax, \& Link, 2016; Mohrman, Tenkasi, \& Mohrman, 2003; Rerup \& Feldman, 2011) and at the individual level (e.g., Bailey \& Raelin, 2015; Brunton \& Matheny, 2009; Helpap, 2016). In this study, by contrast, we are interested in the effects of an organization development process on transitions in the personal schemata of participants.

Walsh (1995) explains that schemata organize knowledge and can therefore change in terms of content or structure. Walsh notes that, although schemata content and structure are conceptually interwoven, issues of both content and structure have rarely been considered simultaneously in research studies and he called for studies into how schemata content and structure interweave. It follows that a study into transitions of both schemata content and structure is likely to provide a novel contribution to the literature regarding cognition in organizations, or more specifically to the literature regarding organizational change. However, Walsh (1995, p. 285) warns that, in the field of knowledge structures or schema, "researchers must confront tricky measurement issues to do empirical work in this area".

An improved understanding of the differences between the two identified types of cognitive transition should provide those concerned with organization development (OD) and other forms of planned change, with a better understanding of why different approaches to each type of change may be necessary. In other words, it is of both theoretical and practical import to better define the types of cognitive transition. This study draws on literature from the field of adult learning theory to better define and operationalize the schema content and schema structure constructs. An empirical study based on these refined definitions is described.

The longitudinal study described here examines the cognitive transitions of participants during an organization development intervention designed to ease the merger of two departments in one organization. The research investigates these personal cognitive transitions by focusing on changes in participants' opinions of the organization and the merger. The specific research question addressed is: How do personal schemata change during an OD intervention and how are these transitions associated with the characteristics of the intervention? This is in line with Balogun and Johnson's $(2005$, p. 1574) statement that the key to understanding how change develops in organizations is to understand "recipient interpretations of change plans, and how these interpretations are mediated by their existing context of action, ways of thinking, and interactions with others". 
We begin the literature review by looking at how the organizational change literature has defined changes in the content of schemata and in the structure - or form - of schemata. Definitions for the two types of transition are then refined into more suitable operationalizable forms, by drawing on literature from the field of adult learning. These deduced constructs are used to guide the empirical stage of the research. In the methods section, we describe the actual change process at our field site and the interview, diary, and observational data collection activities. We also describe the qualitative analytical strategy employed. In the results section, we explain how another kind of cognitive change we weren't originally looking for, emerged. We also review the results on the linkages found between characteristics of the change process and the cognitive transitions observed. In the final section of the paper we discuss the results and their implications for our understanding of the practice of organization development.

We believe the study contributes to the theoretical and practical understanding of organizational change by providing operational definitions of changes in form and content of schemata, by identifying a third type of transition which we term cognitive effort, and by linking these three types of transition to characteristics of change interventions.

\section{Cognitive Transition During Organizational Change}

Much of the most relevant work on of how schemata may change during organizational change has been done by Bartunek and associates (Bartunek, 1984; Bartunek et al., 2011; Bartunek \& Moch, 1987). Referring to the ways that schemata may change, Bartunek (1984, p. 356) says

“...there are two ways interpretive schemes may change. Watzlawick, Weakland, and Fisch (1974) described first-order change as incremental modifications in present ways of interpretation. Second-order change, on the other hand, is a radical, discontinuous shift in interpretive schemes: organizational paradigms are reframed, and norms and world views are changed."

Levy and Merry (1986) cite 19 different examples of definitions and descriptions of first-order and second-order change from a range of scientific fields, summarizing that the distinguishing feature is that, unlike first-order change, second-order change involves a paradigmatic shift. In terms of individual cognitive transition in organizations, schemata, although enduring, can be changed (Bartunek, Gordon, \& Weathersby, 1983; Labianca, Gray, \& Brass, 2000). Breu and Benwell (1999) describe first-order cognitive transition as a change in content with no change in the existing frames of reference- or world view-and they 
describe second-order cognitive transition as a change in context with an associated transformation of individual frames of reference to a new world view.

Given the apparent importance of differentiating between types of cognitive transition during organizational change it is essential to define each type of transition in a way which is suitable for its identification and operationalization. However, the definitions drawn here from the organization literature appear, on closer inspection, to be rather vague and hence prone to overly subjective interpretation. For example, is the realization of the need for participative management a change in schemata content or context? Similarly, is the realization of the need to be assertive towards senior management a change in schemata content or context? This concern is in line with the warning from Walsh (1995) about the difficulties of measurement regarding schemata.

One scholar interested in planned change says that his thinking has "evolved from theorizing about 'planned change' to thinking about such processes more as 'managed learning"" (Schein, 1996, p. 27) which leads us to consider schemata transition during organizational change from a different angle. Olson and Hergenhahn (2009, p. 7) describe learning as "a general term that is used to describe changes in behavior potentiality resulting from experience". As organization development aims to change potential behavior there is a clear link between OD and learning. Hence, in the second part of this review, cognitive transition is considered from the perspective of learning theory, or more specifically, from the perspective of adult learning theory.

\section{Cognitive transition from the adult learning perspective}

Jean Piaget (1896-1980) made a foundational contribution to the cognitive perspective on learning theory based on his interest in how intellectual potential develops. Central to his theories was the concept of schemata. He defined two poles of an interaction between the organism and the environment with the concept of assimilation, which is the process by which an organism responds to the environment in accordance with its existing cognitive structure, and the concept of accommodation, which is the process by which unique aspects of experiences cause a cognitive disbalance resulting in changes to the existing cognitive structures (Piaget, trans. 1957; Wadsworth, 2004).

Mezirow (1991) proposed that, in adulthood, intentional action is taken by people to resolve contradictions that existing schemata cannot handle. His theory of transformative learning subsequently became the most researched and discussed theory in the field of adult education (Cranton, 2006; Merriam, Caffarella, \& Baumgartner, 2007; Taylor, 2007) and has 
been used to understand issues in organizational change (Donovan, Meyer, \& Fitzgerald, 2007; Gilpin-Jackson, 2015). Mezirow (2012, p. 85) says that "transformative learning refers to transforming a problematic frame of reference to make it more dependable in our adult life by generating opinions and interpretations that are more justified".

Despite the impact of transformative learning theory, Cranton and Taylor (2012) note concerns about the lack of clarity around the related terminology. Similarly, in an earlier paper, Taylor (2000, p. 293) says that Mezirow's "conceptual construction of a frame of reference, inclusive of meaning schemes though grounded theoretically, lacks a strong empirical foundation".

With reference to Piaget's concepts of assimilation and accommodation, Kegan (2000, pp. 48-49) highlights the importance of considering the ways people learn when he differentiates between in-form-ative learning which "seeks to bring valuable new contents into the existing form of our knowing" and trans-form-ative learning which "puts the form itself at risk of change". He says that he wishes to "try to protect the genuinely landscape-altering potential in the concept of transformational learning" (p. 47) and suggests that the concept of a subject-object relationship forms the crux of differentiating between types of learning:

"That which is "object" we can look at, take responsibility for, reflect upon, exercise control over, integrate with some other way of knowing. That which is "subject" we are run by, identified with, fused with, at the effect of .... When a way of knowing moves from a place where we are "had by it" (captive of it) to a place where we "have it" and can be in relationship to it, the form of our knowing has become more complex, more expansive. This somewhat formal, explicitly epistemological rendering of development comes closest, in my view, to the real meaning of transformation in transformational learning theory.” (Kegan, 2000, pp. 53-54)

Taylor and Snyder (2012, p. 48) comment that “Kegan's (2000) perspective . . o offers a meaning to further distinguish transformative learning from other forms of learning”. Kegan's (2000) concept of considering types of learning in terms of subject-object theory not only appears to provide operationalizable definitions but also explains from a theoretical perspective why such differentiation is significant in terms of complexity of thought. From the field of OD, Bartunek et al. (1983, p. 275) say that the ability to consider new perspectives generally leads to more effective behavior and that "the end goal of adult development is committed action based on complex understanding". Hence, defining types of change in the field of OD in a way which is related to increasingly complex thinking makes good sense from both a theoretical and a practical point of view. 
By drawing on Kegan's (2000) concepts of informative and transformative learning and his concept of subject-object change, this study distinguishes between two types of personal cognitive transition, namely changes in the content of schemata and changes in the form of schemata. Changes in the content of schemata occur when new content is brought into the existing schemata but there is no change in subject-object balance in the schemata. Changes in the form of schemata occur when something which was subject in an individual's schemata now becomes object-where previously the individual was had by it (captured by it) to where the individual has it and can be in a relationship to it. These two types of cognitive transition, as drawn from extant literature, are used to guide the empirical stage of the research.

It is important to emphasize that the study here, although based on Kegan's (2000) subject-object theory, does not consider his related theories concerning qualitatively different stages of human cognitive development. Whilst a subject-object change in relation to a specific aspect arising from participation in an organizational change intervention may well be indicative of a micro-step increase in complexity of thought it is beyond the scope of this study to consider relationships to, or even the existence of, differentiated stages in human development.

\section{Research Design, Site, And Methods}

The aim of the research was theory building based on investigating contemporary phenomena in depth and within their real-life context. Hence, the research adopted a multiplecase study design with a predominantly qualitative methodology. French and Bell (1999) highlight the potential difficulties regarding internal validity in research in the field of OD. They ask whether observed changes can be directly attributed to the OD intervention and they recommend theory-guided research for investigating OD interventions, saying that "theoryguided research is more efficient, more precise, and more definitive. With theory, researchers know what to look for in their research efforts" (p. 306). In this study, theory-guided research was conducted where changes in the content of schemata and changes in the form of schemata were investigated within the contexts of the activities of a single OD intervention. By conducting the research within the context of a single OD intervention, the characteristics of the change intervention were ostensibly the same for all participants.

\section{The OD Intervention}

The host organization for the main study (Seibank, a pseudonym) was selected on the basis that it was about to embark on a change intervention aimed at transformational 
organizational change. The organization is the retail banking division of a major banking group in South Africa. Following a recent merger of two business units within the division, 45 of the more than 2000 affected employees were randomly selected from the affected job roles and four different regional offices to participate in an intervention aimed at overcoming concerns about the merger which had been openly voiced by employees. All 45 invited employees agreed to participate in the process. The objective of the intervention was cultural in nature and was framed as Merging to Create a Great Place to Work.

The type of intervention, for both a pilot study and the main study, was an Appreciative Inquiry (AI), a prominent form of Dialogic OD (Bushe \& Marshak, 2014; By, Oswick, \& Burnes, 2014). Bushe and Marshak (2009) explain that, whereas Diagnostic OD involves collecting valid data which are assumed to reflect an objective reality and which are used to compare performance against a desired future state, Dialogic OD is focused on engaging stakeholders in new conversations that aid in the establishment of better ways of organizing. The intervention at Seibank was facilitated by an expert AI facilitator and followed the typical 4 D cycle (Cooperrider, Whitney, \& Stavros, 2008). Each of the four phases: discovery, dream, design, and destiny were conducted in separate full-day workshops spaced some three weeks apart from each other.

At the Discovery workshop the participants were asked to discuss moments when they felt the bank had been a great place to work, when they had personally successfully navigated a transition, and an example of where the merger had worked well. At the end of the workshop a video was shown entitled The Color Changing Card Trick aimed at emphasizing the selectivity of human information-gathering processes. At the Dream workshop the emerging themes from the discussions at the previous workshop were summarized under the headings of organization, individual, and leadership. After a futuring exercise, groups were asked to develop possibility statements based on everything being right at the bank in five years' time. The Design workshop commenced with the showing of a video entitled Celebrate what is Right with the World. Participants then chose to join one of three groups in order to address themes that had emerged under the categories of organization, individual, and leadership. Each group was requested to indicate actions required, stakeholders needed, how to secure their buy-in, and resource implications in respect of the relevant themes. At the Destiny workshop a list of recommendations and individual commitments was compiled. 


\section{Case Selection}

Consent was obtained from all 45 who participated in the appreciative inquiry to be part of the research study. In line with recommendations by Yin (2014) and Eisenhardt (1989) for multiple-case study research, only six of the participants were selected as cases. Yin (2014, p. 31) suggests the use of six to ten cases and Eisenhardt (1989, p. 545) recommends between four and ten cases saying that

with fewer than 4 cases, it is often difficult to generate theory with much complexity, and its empirical grounding is likely to be unconvincing .... with more than 10 cases, it quickly becomes difficult to cope with the complexity.

Yin (2014) proposes various methods for selecting cases, including selection on the basis of cases predicting similar results. In order to investigate cognitive transition throughout the change process, we chose to study individuals who were entering the intervention in a non-transitioned state as indicated by their generally negative opinion of the merger of the two business units. The cases were selected using data collected at the pre-intervention stage from all 45 participants by means of diary responses aimed at assessing their opinion regarding the merger using open-ended questions such as: (a) Using three or more sentences, please describe your opinion of the initiative; (b) Please describe how the initiative makes you feel now; (c) Please describe how your behavior may have changed as a result of the initiative; (d) What do you currently think of this bank as being a great place to work?; (e) Please describe any changes you feel are needed at work; and (f) How important are these changes for you? More than $80 \%$ of the 45 participants were generally negative about the merger at the pre-intervention stage and the sample of six was chosen from amongst them to achieve a representative spread of job roles and demographics from a range of regional offices. Demographic parameters included length of service, age, gender, and home language. The six cases represented a reasonable spread on all of these parameters. A parameter where the spread may be considered to be limited was gender where only one of the six cases was male. However, the general spread of demographics amongst the cases is considered adequate for the purposes of the study. Demographics for the six individuals, selected as caseslabelled using pseudonyms — are shown in Table 1. -insert Table 1 about here

The recent merger at Seibank entailed integrating the previously independently managed private banking division into the retail banking division. As a result structures, processes, mandates, and employee locations were affected. Two of the six selected cases 
were managers. Bernice, a Branch Manager, and Lala, an Area Manager, had to take on significantly deeper and broader management responsibilities as a result of the merger. Four of the selected cases were previously part of the private bank, Allison was a Business Banker and Eddie, Maria, and Susan were Personal Relationship Bankers. Following the merger, they had to report into what were previously retail banking management structures. Whereas, Allison and Eddie, remained in the same office locations, Maria and Susan had to move from a private banking suite into a retail bank branch.

\section{Data Collection}

Data were collected six times from each case-once prior to the intervention, four times during the intervention, and once after the intervention-resulting in thirty six data collection points which is in line with recommendations to achieve saturation (Guest, Bunce, \& Johnson, 2006). In addition to collecting data at different points in time, different data collection methods were used in order to triangulate the data.

At the pre-intervention stage, data were collected by means of diary prompts consisting of 12 open-ended questions (including six described above) regarding the respondent's feelings, opinions, and behavior relating to the merger. Respondents were also asked to describe any changes they felt were needed at work and whether they were confident such changes could be made. Respondents were asked to answer each prompt using three or more sentences.

During the intervention, data were collected by direct observation by the first author whilst each of the four intervention workshops was in progress. The observation included any comments made by the participants during the workshops. Data were also collected immediately following each of the workshops by means of diary prompts, consisting of eight open-ended questions. Respondents were asked to describe, using three or more sentences per prompt, their opinion of the bank and their opinion and learnings regarding the day's workshop. The combination of self-reports and direct observation was used in order to reduce possible limitations due to either actions or written accounts being self-censored.

At the post-intervention stage, data were collected by the first author through interviews. The semi-structured interview questions probed for opinions and feelings about the bank and about the merger at three points in time: before the intervention, during the intervention and following the intervention. The questions were adopted from Isabella's (1990) study of managers' changing cognitive patterns associated with an organizational change process, in which she collected data about changes to participants' frames of 
reference - or schemata - by means of retrospective semi-structured interviews. The derived questions included: (a) If you think back to just prior to the AI intervention, to what extent did you feel that there was a need for change? (b) If you think back to just prior to the AI intervention, please tell me more about your opinion, at that time, of the alignment initiative; (c) What do you currently think of the bank as a great place to work? (d) What is your current opinion of the alignment between RRB and branch networks? (e) How did your opinion of the bank as a great place to work change as a result of the Appreciative Inquiry process? (e) Which activities in the Appreciative Inquiry workshops may have particularly influenced any change in your thinking about the bank as a great place to work? and (f) Which activities in the Appreciative Inquiry workshops may have particularly influenced any change in your thinking about the alignment between RRB and branch networks? The interview guidelines were designed with a one-hour duration for each interview in mind. The interview instrument was modified as a result of the analysis of the data collected at the pre-intervention and during-intervention stages, as described in the following section.

\section{Data Analysis}

Data collected before and during the intervention by means of diary responses and direct observation were analyzed by means of a conventional qualitative analysis technique (Hsieh \& Shannon, 2005) in which codes were derived, bottom-up, from the data. During this analysis the intent was to identify transition themes. This initial analysis was conducted before the post-intervention interviews and allowed for the refinement of the interview guide to gather data on each of the already identified transition themes. This granular approach to transition per theme complies with Walsh's (1995, p. 285) argument regarding schema theory that a "knowledge structure theory must make a commitment to particular content schemas . . . schemas are specific to various information domains".

The post-intervention interviews were analyzed by a top-down, direct content analysis technique (Hsieh \& Shannon, 2005) in which the initial codes were drawn from categories identified during the literature review and/or identified from the conventional analysis of diary data. The combination of conventional and direct analysis techniques in the study represents a form of triangulation which helps to overcome the limitations of each technique. The direct content approach helps ensure that key categories are identified and the conventional approach helps to minimize the effect of preconceived biases of the researcher.

The overall analytical process commenced with within-case analyses followed by cross-case analysis. The intent of the within-case analyses was to identify categories and their 
links relating to each individual case and the purpose of the cross-case analysis was to identify patterns amongst the cases. The cross-case findings were then considered in the light of the extant literature.

Data saturation was assessed in this study by graphing the accumulative number of categories against the number of coded cases to measure when new information resulted in little or no change to the process (Guest et al., 2006). Of the 53 identified categories, 45 were assigned or identified during the coding of the first case. This represents $85 \%$ of the total categories. By the time that coding of the fourth case had been completed, 52 categories, representing $98 \%$ of the total categories, had been assigned. These results are considered to show adequate evidence of saturation and it can be concluded that the number of purposive samples was adequate for the purposes of the research.

\section{Results}

A description follows of the analysis process which led to the identification, from the data, of a range of transition themes which were then classified into three types of transition. The relationship between certain characteristics of the intervention and the types of transition is then specified.

\section{Transition themes and the types of transition}

The within-case analysis process led to the identification of ten different transition themes from a total of 25 reports of transition amongst the six cases. These transition themes were: (a) the bank as caring about employee opinions; (b) the bank as a great place to work; (c) learning about the impact of the merger on subordinates; (d) opinion of the merger; (e) learning to look at the bigger picture of organizational change; (f) learning about the need for participation in organizational change; $(\mathrm{g})$ learning regarding the ability to choose how to react to change; (h) assertiveness towards those more senior in the management hierarchy; (i) putting the merger behind him/her; and (j) positive attitude towards an organizational-change out there. The data for each individual, as collected by means of diary prompts, observations, and interviews, were analyzed longitudinally in respect of each of the themes for which they transitioned. For example, Susan transitioned on five different themes and representative quotations for each of her transitions are shown, in a longitudinal format, in Table 2. -insert Table 2 about here-

Changes in the content and/or form of schemata. Nine of the total of ten transition themes fit into the two pre-identified types of cognitive transition as either a change in the content of schemata or a change in the form of schemata. 
An example of change in schemata content was Lala saying that she felt better "knowing that someone out there cares". This was new knowledge —or an insight—which she did not have before but there was no change in her subject-object balance. Similarly, Maria transitioned in terms of the content of her schemata regarding her opinion of the merger. When asked, prior to the intervention, about how she felt about the merger she replied "not good at all" whereas in response to the same question asked after the intervention she replied "at the end of the day, the alignment was a good thing, it was a really worthwhile in the eyes of making the life of the clients' better, to ease their life". Further examples of changes in content of schemata can be seen in the first four transition themes for Susan in Table 2.

An example of a change in the form of schemata was Lala's desire to be more assertive towards management above her. She said that her behavior "has changed toward leadership. I feel that I want to share my personal opinions”. In her mind, senior management changed from subject to object. Whereas before the intervention she was had by senior management - considering her relationship to them as being fixed and outside her control- during the intervention she realized that she could determine her relationship to them. Another example of a change in the form of schemata was Susan's new ability to be creative with how she made sense of information, as reflected in the following dialogue:

Researcher: A change happened, let's take the merger ... Do you think, if you take a positive attitude, you see that change differently?

Susan: Definitely, yes.

Researcher: But it's the same change, the same thing has physically happened. Susan: No, it's just depending how you see it in your mind.

Researcher: Ok. So you can create your own reality, would you say?

Susan: I don't think I can create my own reality, but I think I can definitely be creative with how I'm going to take that information.

Change in content following from changes in form. The change in the form of Susan's schemata resulted in her redefining her situation and consequently changes occurred in the content of her schemata. For example, before the intervention she despised having to work in a branch: "I hate working in a branch I hate it....So, you know when you just hear one day you're going to move back to the branch, it's not a nice feeling. It's horrible, I don't want to be in the branch". However, following the intervention she reported a vastly different opinion about being located in a branch saying “you know when we're here and we're visible to our clients and to the branch staff ... I can help them now or they can help me". When asked if she saw this as being important before the 
intervention she stated that she didn't want to see it as being important, as is shown in the following extract:

Researcher: You said that you being here physically, there's some advantages to it?

Susan: There's definitely some advantages, yes.

Researcher: So would you say you now see that as being quite important?

Susan: Oh yes, very important yes.

Researcher: And do you think you saw it as important before?

Susan: No, I didn't want to see it.

Similarly, the form of Lala's schemata changed in that she learnt she could put the merger behind her. She said

what really made me feel sort of satisfied in the end was because you realize ok, you know what, this thing [the merger] happened, it happened, we need to really move on. You can't keep going back to those feelings, there was no use going back to those feelings you know? So I wanted to move on so this [the intervention] allowed me to like sort of think, feel and push things away.

This change in the form of schemata enabled a change in her schemata content regarding her opinion of the merger, as highlighted in her description of the closure process as "a psychological aspect that needs to be dealt [with], we don't realize it as we go along, but afterward you realize that, you know what, I actually did benefit from this thing [the intervention]". Hence, a change in the form of schemata can lead to a change in schemata content.

Identification of a third type of transition. The cross-case analysis identified that four of the six individuals transitioned in terms of adopting a positive attitude towards an organizationalchange out there. For example, Lala said "we've got to be very positive in terms of change . . .. you are not necessarily going to have change that's going to be in your favor" and Eddie said at the end of the final intervention workshop that he was "starting to look at things in a positive way even if the situation doesn't look positive". When asked about the merger at the post-intervention interview, Eddie said "there's a lot of pain in it" and he was of the view that it would be unwise for him to stay long in the division. These reactions to the organizationalchange indicate that, despite Lala and Eddie's attempts to be positive, they still felt captive of the change and that, for them, the organizational-change was out there as a single external reality. 
The adoption of a positive attitude towards an organizational-change out there transition theme did not fit the categories of change in content of schemata or change in form of schemata. There is no real change in terms of acquiring new knowledge (content) and, although the perceiver strives to see the particular organizational-change more positively, there is no real change in subject-object balance. The organizational-change has perhaps become slightly less subject as the perceiver is no longer entirely controlled by it, but it has not become fully object in that it is still a fixed reality which still largely controls them. Their choosing to view it positively is not accompanied with a view that the reality itself has changed - they choose to view a fixed reality more positively.

A third type of transition was therefore identified and labelled development of an appreciative stance, defined as striving to see something positively without a change in subject-object relations. Hence, a finding is that, in addition to the cognitive transitions of changes in the content of schemata and changes in the form of schemata, employees can transition during an appreciative inquiry intervention in terms of developing an appreciative stance. The transition themes for the three different cognitive outcome patterns are shown in Table 3. insert Table 3 about here

\section{Degree of transition.}

It was found that the degree of transition - defined as the extent to which the individual transitions in line with the intervention change objective - can vary greatly amongst participants. For example, whilst Lala transitioned in line with the objective of the intervention in seven different transition themes, Bernice only transitioned in line with the objective of the intervention in one transition theme and actually transitioned in the opposite direction to the objective in two of the other transition themes. The intervention made Bernice realize that the future was not looking positive and that she could choose to leave the bank. She said: "I need to make a decision as to where I want to be. . . it made me think about where the bank is now and where it's going to and do I want to be still on that same journey with them?" She did not feel that she had a real choice of how to react to change. She emphatically said "well you don't have a choice, you do have a choice, you have two choices. You can either fit in, accept it, deal [with] it and get on with the program or you can leave". She also doubted whether adopting a positive attitude could make any difference, saying "it's ok to look at things positively and to talk positively and to feel positive and to think positive. Whether your positivity's going to rub off on the next one and actually have an impact, I 
don't know about that". The number and direction of transitions for each individual is shown, in descending order, in Table 4.

-insert Table 4 about here-

\section{Impact of the intervention characteristics on transition}

Identifying the intervention characteristics. In order to better understand the conditions that lead to the different types of transitions, their relationships with the characteristics of the intervention, as reported by each individual, were examined. For example, the representative quotations linking each of Susan's five transition themes to four different characteristics of the intervention which were influential on that transition are shown in Table 5.

insert Table 5 about here-

The within-case analysis of the 25 instances of transition amongst the six cases led to the identification of a total of ten different intervention characteristics. The different intervention characteristics which were identified were: (a) Top management initiated the AI process; (b) An environment in which participants felt free to talk openly; (c) Becoming aware of the viewpoints of others; (d) The content of the change process being determined by the participants; (e) The unconstrained and holistic nature of the change process; (f) The envisioning a positive future activity; (g) Watching the positive videos; (h) Focusing on solutions; (i) The positive attitude of the facilitator; and (j) Completing the pre-intervention diary response form. The intervention characteristics for the instances of transition for each transition theme per case are summarized in Table 6.

-insert Table 6 about here

Three categories were identified into which the ten intervention characteristics could be clustered. The first of these categories was an engaging, emergent change process, defined as a change process that encourages participants to interact and talk freely in order to determine the content of the change process. The intervention characteristics of: (a) the content of the change process being determined by the participants; (b) the unconstrained and holistic nature of the change process; (c) an environment in which participants felt free to talk openly; (d) becoming aware of the viewpoints of others; and (e) completing the preintervention diary form, were clustered into this category. A second category was the positive focus of the change process. The intervention characteristics of: (a) the envisioning a positive future activity; (b) watching the positive videos - consisting of The Color Changing Card Trick and the Celebrate what is Right with the World videos; (c) focusing on solutions; and (d) the positive attitude of the facilitator, were clustered into this category. A third 
intervention characteristic category was top management initiated the AI process. While this could be related to either of the first two, it's consistent relationship to one transition theme, described below, suggested keeping it separate was more illuminating. The categories of intervention characteristics are summarized in Table 7. -insert Table 7 about here-

Relationships between ten transition themes and three intervention characteristics. Five of six individuals had the same transition of gaining an improved view of the bank as caring about employee opinions. This is a change in schemata content but the strength of the crosscase pattern makes it worth noting separately. The single intervention characteristic linked to this transition in all five instances was top management initiated an AI process. The only individual who did not transition regarding an improved view of the bank caring about employee opinions was Bernice. Her mistrust in the integrity of top management was evident, even after the intervention. For example, she said "yes we've done this and I think it's...to me it's like they're wallpapering. They haven't sorted out the rot behind the wall, they've just painted it white so it looks pretty".

Of the remaining 12 instances of changes in schemata content that were in line with the objective of the change intervention, 11 were associated with an engaging emergent change process and one was associated with the positive focus of the change process. Of the five intervention characteristic categories associated with the three instances of changes in the form of schemata, one was top management initiated an AI process, three were an engaging emergent change process and one was the positive focus of the change process. The intervention characteristic categories for the transitions are shown in Table 8.

-insert Table 8 about here-

Of the six intervention characteristic categories given for the four instances of development of an appreciative stance, one was an engaging emergent change process and five were the positive focus of the change process.

\section{Discussion}

The empirical stage of this research commenced with clearly defined and well operationalized constructs for changes in the content and form of schemata. It focused on changes in employee opinions regarding granular transition themes mainly related to the organization and/or the merger. The results show that the degree of transition can vary greatly amongst participants in an organizational change process and the research provides a better 
understanding of: (a) the types of transition which may occur; (b) possible links between the types of transition; and (c) likely associations between the types of transition and the intervention characteristics. The results of the research are discussed here under the headings of theoretical contribution and implications for practice. The limitations of the study and recommendations for further research are given.

\section{Theoretical contribution}

The study shows that changes in both content of schemata and form of schemata can occur for employees participating in an organization development process. The results also show that changes in schemata content can result from changes in the form of schemata. Defining both types of cognitive transition in terms of subject-object theory not only helps to better identify each type of transition, but also helps to provide a better understanding of their inter-relatedness.

The finding that changes in schemata content can occur as a result of changes in the form of schemata can be explained by Kegan's (2000: 54) argument regarding 'trans-formative' learning that

"when a way of knowing moves from a place where we are "had by it" (captive of it)

to a place where we "have it" and can be in relationship to it, the form of our knowing has become more complex, more expansive'."

So, for example, once an organizational change becomes object for an employee they are likely to develop new - and more complex - insights regarding aspects of that change. Hence, a change in the form of schemata can represent a form of 'unfreezing' in which situations are redefined-paradigms are shifted - and thereby pave the way for changes in schemata content. The study shows how such an unfreezing process can occur in an OD intervention which has a focus on positivity.

The study also shows that, in addition to changes in the content of schemata and changes in the form of schemata, the development of an appreciative stance is a type of personal transition which may occur during an appreciative inquiry. To assess what kind of transition this is, we returned to Kegan's theory. Kegan (1994, p. 256) describes "directing one's energies to live better in the world as one constructs it, rather than directing one's energies to reconstructing it" as a form of coping. It is not apparent that he classifies coping as an alternative type of learning to either informational learning or transformational learning. Folkman (1984, p. 843) defines coping as "cognitive and behavioral efforts to master, reduce, or tolerate the internal and/or external demands that are created by the stressful transaction" 
and emphasizes that "coping is defined independently of its outcome". As learning —or cognitive transition - has been referred to as a change in behavior potentiality it differs from coping in that learning is defined in terms of an outcome of an experience as distinct from coping which is an effort in response to an experience.

The development of an appreciative stance in response to organizational change therefore appears to be a cognitive effort — or conative response - as distinct from a cognitive outcome. Carver, Scheier, and Weintraub (1989, p. 269) identify emotion-focused coping-as distinct from problem-focused coping - as "aimed at managing distress emotions rather than dealing with the stressor per se". They explain that emotion-focused coping occurs when people feel that the stressor must be tolerated and therefore may unsustainably mask discontent. Similarly then, the development of an appreciative stance may reflect a perception of being unable to influence the stressor per se. Hence, the identification of the development of an appreciative stance as a coping form of personal transition during organizational change may, for example, explain findings that heightened positive affect during AI is not correlated with sustained change (Bushe, 2010; Wright \& Baker, 2005).

AI, as a form of Dialogic OD has a particular emphasis on positivity. However, Dialogic OD approaches in general focus on positive anticipations of the future rather than understanding how problems came to be (Bartunek et al, 2011; Bushe \& Marshak, 2015). Therefore, it is possible that Dialogic OD in general may lead to participants developing an appreciative stance. The implication being that such transition, which may be common in Dialogic OD, may well involve positive affect but might not be either transformational or sustainable.

The study suggests, however, that the engaging emergent nature of the change process, more than its positive focus, is responsible for changes in schemata content and/or form. This is a potentially significant contribution to the study of types of OD, such as AI, which include a focus on the positive, and supports the emergence hypothesis put forward by Bushe and Marshak (2014). A growing number of scholars are questioning the importance of the positive to AI outcomes (Bushe, 2007, 2013; Fitzgerald, Oliver, \& Hoxsey, 2010; Johnson, 2013) but these have mainly been framed as a question of whether it is positivity or generativity that is at the heart of transformational change potential (Cooperrider, 2013). Past empirical studies have been unable to untangle their effects (Bushe, 2010). The present study appears to show that positivity did not have much impact on transitions in individual schemata and foregrounds the role of emergence, rather than generativity, in personal transitions during organizational change. As such this study offers an explanation at the 
individual level for Bushe \& Kassam's (2005) finding that an improvisational (or emergent) approach to the action phase in $\mathrm{AI}$ is associated with more transformational outcomes.

In summary, the study has found that cognitive transition can occur during an OD intervention in terms of changes to the content of schemata and changes to the form of schemata and that both types of cognitive transition are associated with an engaging emergent change process. Changes in the form of schemata represent increased complexity of thought which can lead to changes in schemata content. The study also identifies the development of an appreciative stance as a form of transition and associates it with the positive focus of a change process. However, this type of transition is a type of cognitive effort, better understood as a form of coping rather than a type of cognitive transition.

The study also found that employees pointed to the initiation of the appreciative inquiry process for explaining their improved perceptions of top management's attitudes toward them. However, we are not sure if we can unequivocally say this improved perception was specifically due to top management choosing an AI process or because they chose a positively focused process or because they choose an engaging emergent process. We can't really tell from this data, but we can conjecture it was one or a combination of those things.

\section{Implications for practice}

The identification of an engaging emergent change process as a key characteristic of interventions to achieve changes in schemata content and/or form can help in better planning and implementation of interventions. For example, these two types of cognitive transition may be facilitated by ensuring the participants determine the content of the change; the content is unconstrained and holistic; that participants appear to be willing and able to talk freely and are listening to each other; and by gathering participant opinions prior to formally starting an intervention.

However, managers should be aware that the intervention described here was designed so that ideas and proposals for change would emerge from key stakeholders but still be vetted by management. To fully take advantage of an engaging emergent change process, research suggests more change happens more rapidly when those proposing ideas are encouraged to act them without waiting for managers to vet them (Bushe \& Kassam, 2005; Roehrig, Schwendenwein \& Bushe, 2015; Rowland \& Higgs, 2008)

Managers should be aware that the mere act of initiating an OD process like appreciative inquiry can improve the perception of employees towards the organization as 
one that cares about their opinions. They need to understand, however, that this may not be enough to change the opinions of employees who mistrust top management's integrity in initiating the intervention.

Intervention facilitators need to be mindful that although a focus on positivity during an intervention may lead to participants adopting an appreciative stance, if the intervention does not achieve sufficient participant engagement in an emergent process, there may be limited changes in participant schemata content or form.

\section{Limitations of the study and recommendations for further research}

The 18 months of engagement of the researcher in the field in this longitudinal study, together with the high degree of triangulation - including the combination of conventional and direct analysis techniques-, peer debriefing, and member checks on the data collected at the pre-intervention and during-intervention stages, help to ensure a good level of credibility. The dependability and confirmability of the study were evidenced in an external auditor report and the reliability of the qualitative analysis was tested through intercoder reliability and intercoder agreement. An independent expert in qualitative research methodology, who was not part of the study, was engaged to assist in the reliability tests. In the first test, 25 samples of raw data were allocated by her into ten pre-identified categories of transition themes. The intercoder reliability score was $96 \%$ (24 out of 25 agreements) suggesting a high level of reliability for the coding of the data into the categories in this study. The second test involved allocating each of the ten categories into one of three pre-identified types of transition. Following Campbell, Quincy, Osserman, and Pedersen's (2013) recommendations on how intercoder agreement should be established for exploratory studies, intercoder agreement was calculated after an initial allocation resulted in $70 \%$ agreement and coders discussed their differences. The result was $90 \%$ agreement (9 out of 10) indicating acceptable-to-good level of confirmability for the allocating of the categories into types of cognitive transitions in the study.

Although multiple cases were investigated, as is typical in a qualitative study, transferability of the findings may be limited. The case study was situated in a single intervention, at a financial services organization, in South Africa. The intervention had a particular change objective and an AI approach was used under the guidance of a specific AI facilitator. The study involved only six cases. The cases were purposively selected on the basis that the individuals held generally negative views of the earlier merger. In mitigation of these limitations, Lincoln and Guba (2007) recommend thick descriptive data in order to 
improve the transferability in qualitative research. Due to the nature of this study, thick description of the intervention characteristics was obtained and hence the transferability to other similar contexts and cases is feasible. Transferability of the findings of this study to the context of Diagnostic OD needs to be treated with caution, in particular because the context for this study was an OD intervention which had a positivity focus and which focused on multiple realities and changing mind-sets. However, the applicability to both Diagnostic OD and Dialogic OD of the findings of this study do present opportunities for further research.

By identifying three, well-defined, types of cognitive transitions in individuals during organization development interventions, and their association with certain intervention characteristics, the research has provided a basis from which testable propositions can be developed. The limitations of the study, particularly in that causal relationships have not been rigorously tested and the fact that the final data collection occurred not longer than a few weeks after the completion of the intervention, present opportunities for further research. Future research could ask: Is the development of an appreciative stance likely to occur under OD interventions which emphasize constructing a positive view of the future but do not contain as strong a positivity focus as AI? Are changes in schemata content and form more likely to occur under Dialogic OD than under Diagnostic OD? What intervention characteristics lead to changes in the form of participant schemata as distinct from changes in the content of their schemata? How sustainable is cognitive transition during an organizational change - perhaps to be measured by means of longer term changes in behavior post the intervention? How sustainable is the development of an appreciative stance during an organizational change? And what qualities of appreciative inquiry, it's positive focus, the engaging emergent nature of it, or some combination, leads employees to believe their leaders care about their ideas?

\section{Conclusion}

This study offers fresh insights into the types of changes in mindset during an organization development process. It also provides evidence of the association between these types of changes in mindset and intervention characteristics. The study thereby offers a more theoretically sound base for future theorizing about personal mindset changes during organizational change. It also offers empirical evidence to support Bushe \& Marshak's (2014) emergence hypothesis concerning transformational change and provides some practical guidelines for conducting such engaging emergent change interventions. 
Importantly, by studying employee transition during organizational change in a wellspecified research design, using clearly defined and well operationalized constructs, the research has provided a better understanding of a type of transition in terms of a cognitive effort as distinct from a cognitive transition and thereby provides opportunities for further theorizing and research on what happens to individuals during planned organizational change.

\section{References}

Bailey, J.R., \& Raelin, J.D. (2015). Organizations don't resist change, people do: Modeling individual reactions to organizational change through loss and terror management. Organization Management Journal, 12(3), 125-138.

Balogun, J., \& Johnson, G. (2005). From intended strategies to unintended outcomes: The impact of change recipient sensemaking. Organization Studies, 26(11), 1573-1601.

Bartlett, F.C. (1932). Remembering. Cambridge: Cambridge University Press.

Bartunek, J.M. (1984). Changing interpretive schemes and organizational restructuring: The example of a religious order. Administrative Science Quarterly, 29(3), 355-372.

Bartunek, J.M., Balogun, J., \& Do, B. (2011). Considering planned change anew: Stretching large group interventions strategically, emotionally, and meaningfully. The Academy of Management Annals, 5, 1-52.

Bartunek, J.M., Gordon, J.R., \& Weathersby, R.P. (1983). Developing “complicated" understanding in administrators. Academy of Management Review, 8(2), 273-284.

Bartunek, J.M., \& Moch, M.K. (1987). First-order, second-order, and third-order change and organization development interventions: A cognitive approach. The Journal of Applied Science, 23, 483-500.

Bess, K.D. (2015). The impact of everyday experiences on planned organizational change: Applying schematic change theory to the study of narratives in community-based organizations. Journal of Community Psychology,43(6), 739-759.

Breu, K., \& Benwell, M. (1999). Modelling individual transition in the context of organizational transformation. The Journal of Management Development, 18, 496-520.

Bridges, W. (1986). Managing organizational transitions. Organizational Dynamics, 15, 24-33.

Bruning, R.H. (1994). The college classroom from the perspective of cognitive psychology. In: K.W. Prichard \& R. McLaren Sawyer (Eds.), The Handbook of college teaching: Theory and applications (pp. 3-22). London: Greenwood Press. 
Brunton, M., \& Matheny, J. (2009). Divergent acceptance of change in a public health organization. Journal of Organizational Change Management, 22(6), 600-619.

Bushe, G.R. (2007). Appreciative Inquiry is not (just) about the positive. Organization Development Practitioner, 39(4), 30-35.

Bushe, G.R. (2010). A comparative case study of appreciative inquiries in one organization: Implications for practice. Review of Research and Social Intervention, 29, 7-24.

Bushe, G.R. (2013). Generative process, generative outcome: The transformational potential of Appreciative Inquiry. In D.L. Cooperrider, D.P. Zandee, L.N. Godwin, M. Avital, \& B. Boland (Eds.), Organizational generativity: The Appreciative Inquiry summit and a scholarship of transformation (pp. 89-114). Bingley: Emerald Group Publishing Limited.

Bushe, G.R., \& Kassam, A. (2005) When is appreciative inquiry transformational: A meta-case analysis. Journal of Applied Behavioral Science, 41, 161-181.

Bushe, G.R., \& Marshak, R.J. (2009). Revisioning organizational development: Diagnostic and dialogic premises and patterns of practice. The Journal of Applied Behavioral Science, 45, 348-368.

Bushe, G.R., \& Marshak, R.J. (2014). The dialogic mindset in organization development. In A. R. Shani, \& D.A. Noumair (Eds.), Research in Organizational Change and Development (Vol 22, pp. 55-97). Bingley, UK: Emerald Group Publishing.

Bushe, G.R., \& Marshak, R.J. (2015). Dialogic organization development: The theory and practice of transformational change. Oakland, CA: Berrett-Koehler.

By, R.T. (2005). Organizational change management: A critical review. Journal of Change Management, 5, 369-380.

By, R.T., Oswick, C., \& Burnes, B. (2014). Looking back and looking forward: Some reflections on journal developments and trends in organizational change discourse. Journal of Change Management, 14, 1-7.

Campbell, J.L., Quincy. C., Osserman. J., \& Pedersen, O.K. (2013). Coding in-depth semi structured interviews: Problems of unitization and intercoder reliability and agreement. Sociological Methods \& Research, 42(3), 294-320.

Carver, C.S., Scheier, M.F., \& Weintraub, J.K. (1989). Assessing coping strategies: A theoretically based approach. Journal of Personality and Social Psychology, 56, 267-283.

Cooperrider, D.L. (2013). A contemporary commentary on Appreciative Inquiry in Organizational life. In D.L. Cooperrider, D.P. Zandee, L.N. Godwin, M. Avital, 
\& B. Boland (Eds.), Organizational generativity: The Appreciative Inquiry summit and a scholarship of transformation (pp. 3-67). Bingley: Emerald Group Publishing Limited.

Cooperrider, D.L., Whitney, D., \& Stavros, J.M. (2008). Appreciative inquiry handbook (2nd ed.). Brunswick, OH: Crown Custom Publishing.

Cranton, P. (2006). Understanding and promoting transformative learning (2nd ed.). San Francisco: Jossey-Bass.

Cranton, P. \& Taylor, E.W. (2012). Transformative learning theory: Seeking a more unified theory. In E.W. Taylor \& P. Cranton (Eds.), The handbook of transformative learning: Theory, research and practice (pp. 3-20). San Francisco: Jossey-Bass.

Donovan, L.L., Meyer, S.R., \& Fitzgerald, S.P. (2007). Transformative learning and appreciative inquiry: A more perfect union for deep organizational change. Academy of Management Annual Meeting Proceedings, 1-6.

Eisenhardt, K.M. (1989). Building theories from case study research. Academy of Management Review, 14, 532-550.

Fitzgerald, S. P., Oliver, C., \& Hoxsey, J.C. (2010). Appreciative inquiry as a shadow process. Journal of Management Inquiry, 19, 220-233.

Folkman, S. (1984). Personal control and stress and coping processes: A theoretical analysis. Journal of Personality and Social Psychology, 46(4), 839-852.

French, W.L., \& Bell, C.H. (1999). Organization development: Behavioural science interventions for organizational improvement (6th ed.). New Jersey: Prentice Hall.

Gilpin-Jackson, Y. (2015). Transformative learning during dialogic OD. In G.R. Bushe \& R.J. Marshak, (Eds). Dialogic organization development: The theory and practice of transformational change (pp. 245-268). Oakland, CA: BerrettKoehler.

Greve, H.R., \& Taylor, A. (2000). Innovations as catalysts for organizational change: Shifts in organizational cognition and search. Administrative Science Quarterly, 45(1), 54 80.

Guest, G., Bunce, A., \& Johnson, L. (2006). How many interviews are enough? An experiment with data saturation and variability. Field Methods, 18, 59-82.

Helpap, S. (2016). The impact of power distance orientation on recipients' reactions to participatory versus programmatic change communication. Journal of Applied 
Behavioral Science, 52(1), 5-34.

Hsieh, H-F., \& Shannon, S.E. (2005). Three approaches to qualitative content analysis. Qualitative Health Research, 15, 1277-1288.

Isabella, L.A. (1990). Evolving interpretations as a change unfolds: How managers Construe key organizational events. Academy of Management Journal, 33, 7-41.

Johnson, P.C. (2013). Transcending the polarity of light and shadow in Appreciative Inquiry: An appreciative exploration of practice. In D.L. Cooperrider, D.P. Zandee, L.N. Godwin, M. Avital, \& B. Boland (Eds.), Organizational generativity: The Appreciative Inquiry summit and a scholarship of transformation (pp. 189-207). Bingley: Emerald Group Publishing Limited.

Kegan, R. (1994). In over our heads: The mental demands of modern life. Cambridge, Massachusetts: Harvard University Press.

Kegan, R. (2000). What 'form' transforms? A constructive-developmental approach to transformative learning. In Jack Mezirow \& Associates (Eds.), Learning as transformation: Critical perspectives on a theory in progress (pp. 35-69). San Francisco: Jossey-Bass.

Konlechner, S.W., Müller, B., Güttel, W.H., Koprax, I., \& Link, K. (2016). Sheep in wolf's clothing: The role of artifacts in interpretive schema change. Schmalenbach Business Review, 17, 129-150.

Labianca, G., Gray, B., \& Brass, D.J. (2000). A grounded model of organizational schema change during empowerment. Organization Science, 11(2), 235-257.

Levy, A., \& Merry, U. (1986). Organizational Transformation. New York: Praeger Publishers.

Lincoln, Y.S., \& Guba, E.G. (2007). But is it rigorous? Trustworthiness and authenticity in naturalistic evaluation. New Directions for Program Evaluation, 30, 15-25.

Merriam, S.B., Caffarella, R.S., \& Baumgartner, L.M. (2007). Learning in adulthood: A comprehensive guide. San Francisco: Jossey-Bass.

Mezirow, J. (1991). Transformative dimensions of adult learning. San Francisco: Jossey-Bass.

Mezirow, J. (2012). Learning to think like an adult: Core concepts of transformation theory. In E.W. Taylor \& P. Cranton (Eds.), The handbook of transformative learning: Theory, research and practice (pp. 73-95). San Francisco: JosseyBass.

Mohrman, S.A., Tenkasi, R.V., \& Mohrman, A.,Jr. (2003). The role of networks in 
fundamental organizational change. Journal of Applied Behavioral Science, 39(3), $301-323$

Nigam, A., Huising, R., \& Golden, B. (2016). Explaining the selection of routines for change during organizational search. Administrative Science Quarterly, 61(4), 551-583.

Olson, M.H., \& Hergenhahn, B.R. (2009). An introduction to theories of learning (8th ed.). New Jersey: Pearson Education Inc.

Oreg, S., Vakola, M., \& Armenakis, A. (2011). Change recipients' reactions to organizational change: A 60-year review of quantitative studies. The Journal of Applied Behavioral Science, 47, 461-524.

Piaget, J. (trans. 1957). The construction of reality in the child. New York: Basic Books.

Rerup, C., \& Feldman, M.S. (2011). Routines as a source of change in organizational schemata: The role of trial-and-error learning. Academy of Management Journal, 54(3), 577-610.

Roehrig, M., Schwendenwein, J. \& Bushe, G.R. (2015) Amplifying change: A three phase approach to model, nurture and embed ideas for change. In Bushe, G.R. \& Marshak, R.J. (Eds.) Dialogic organization development: The theory and practice of transformational change (pp.325-348). Oakland, CA: Berrett-Koehler.

Rowland, D.,\& Higgs, M. (2008) Sustaining change: Leadership that works. Chichester, UK: Jossey-Bass.

Schein, E.H. (1996). Kurt Lewin's change theory in the field and in the classroom: Notes toward a model of managed learning. Systems Practice, 9, 27-47.

Taylor, E.W. (2000). Analyzing research on Transformative Learning theory. In J. Mezirow (Ed.), Learning as transformation: Critical perspectives on a theory in progress, (pp. 285-328). San Francisco: Jossey-Bass.

Taylor, E.W. (2007). An update of transformative learning theory: a critical review of the empirical research (1999-2005). International Journal of Lifelong Education, 26, $173-191$.

Taylor, E.W., \& Snyder, M.J. (2012). A critical review of research on transformative learning theory, 2006-2010. In E.W. Taylor \& P. Cranton (Eds.), The handbook of transformative learning: Theory, research and practice (pp. 37-55). San Francisco: Jossey-Bass.

Tsoukas, H., \& Chia, R. (2002). On organizational becoming: Rethinking organizational change. Organization Science, 13(5), 567-582.

Wadsworth, B.J. (2004). Piaget's Theory of Cognitive and Affective Development (5th 
ed.). USA: Pearson Education Inc.

Walsh, J.P. (1995). Managerial and organizational cognition: Notes from a trip down memory lane. Organization Science, 6, 280-321.

Wright, M., \& Baker, A. (2005). The effects of appreciative inquiry interviews on staff in the UK National Health Service. International Journal of Health Care Quality Assurance, 18(1), 41-61.

Yin, R. K. (2014). Case study research: Design and methods (5th ed.). Thousand Oaks, California: Sage Publications, Inc. 


\section{Tables}

Table 1

Demographics for the six individuals selected as cases

\begin{tabular}{llllll}
\hline Name & Job Role & Years at Bank & Age & M/F & Home Language \\
\hline Allison & Business & 9 & $26-35$ & F & English \\
& Banker & & & &
\end{tabular}

\begin{tabular}{llllll}
\hline Bernice & Branch & 31 & $46-55$ & F & English \\
& Manager & & &
\end{tabular}

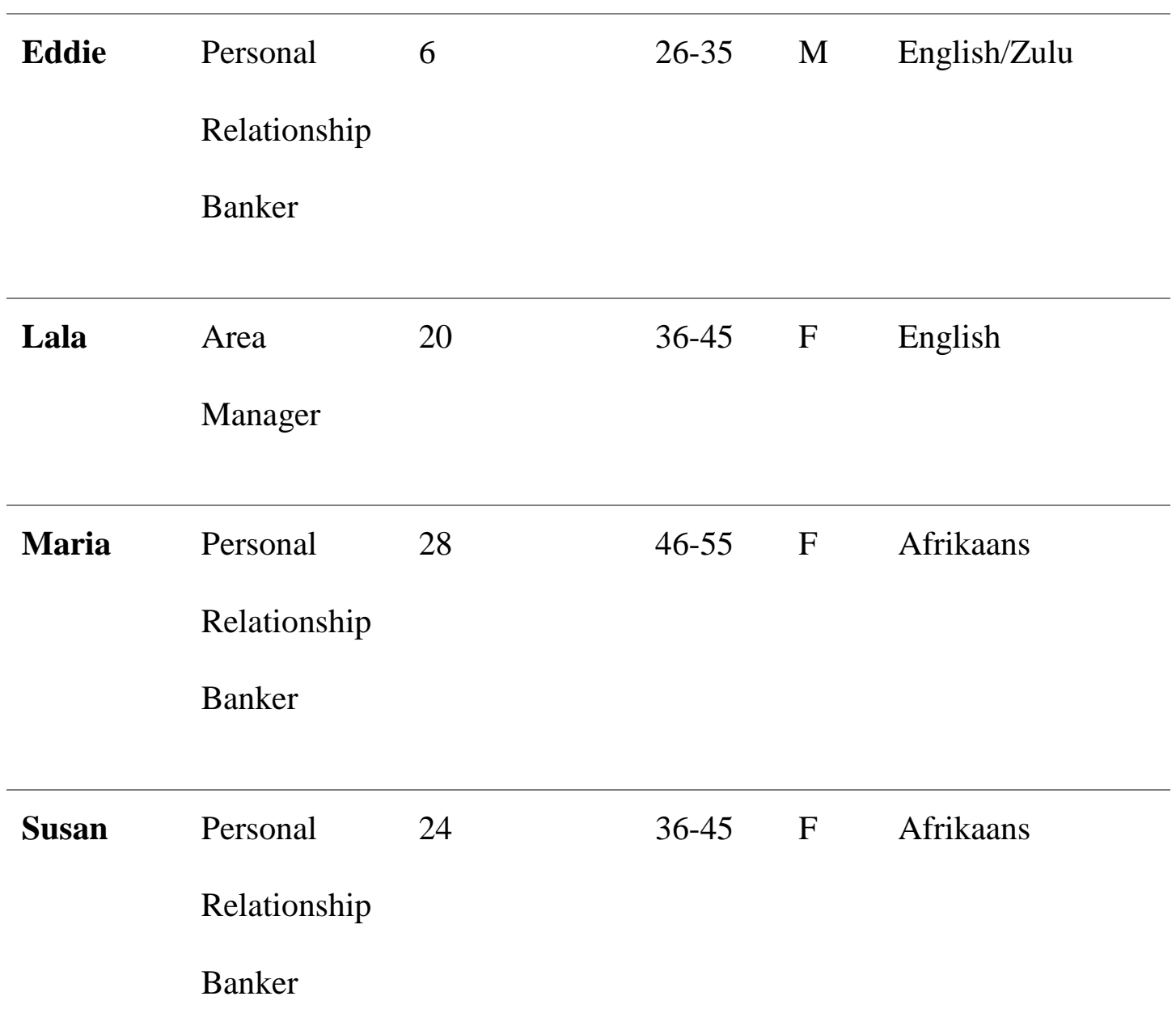


Table 2 Representative quotations for Susan's transitions

\section{Transition theme}

\section{Representative Quotations}

Before the intervention

Discovery

Dream

Design

Destiny

After the intervention

\begin{tabular}{|c|c|c|}
\hline \multirow[t]{3}{*}{$\begin{array}{l}\text { Opinion of the } \\
\text { merger }\end{array}$} & $\begin{array}{l}\text { Interview: I hate working in a } \\
\text { branch I hate it. I hate } \\
\text { working...coming in...dual control, } \\
\text { small little things that I absolutely } \\
\text { hate. So, you know when you just } \\
\text { hear one day you going to move } \\
\text { back to the branch, it's not a nice } \\
\text { feeling. It's horrible, I don't want to } \\
\text { be in the branch, I left the branch } \\
10 \text { years ago. }\end{array}$ & $\begin{array}{l}\text { Observation: Displayed } \\
\text { negative body language by } \\
\text { turning her body away and } \\
\text { looking cross with down- } \\
\text { turned pursed lips when a } \\
\text { colleague spoke positively } \\
\text { about the alignment. } \\
\text { Observed to say: It is } \\
\text { difficult for me to say what } \\
\text { is positive, nothing worked } \\
\text { for my clients. }\end{array}$ \\
\hline & $\begin{array}{l}\text { Diary: The only change that I think } \\
\text { could possibly be positive is the } \\
\text { cost saving. }\end{array}$ & $\begin{array}{l}\text { Diary: It was difficult for } \\
\text { me to think of one positive } \\
\text { or what worked well with } \\
\text { the alignment from } \\
\text { relational banking to retail. } \\
\text { Unfortunately nothing } \\
\text { positive came to mind. }\end{array}$ \\
\hline & $\begin{array}{l}\text { Interview: It was like degrading to } \\
\text { our clients. }\end{array}$ & $\begin{array}{l}\text { Diary: Disappointed and } \\
\text { angry as the initiative [the } \\
\text { merger] did not benefit me } \\
\text { or my clients in any way. I } \\
\text { am now situated in a } \\
\text { branch, they do not } \\
\text { understand our role or our } \\
\text { clients' needs. }\end{array}$ \\
\hline
\end{tabular}

$\begin{array}{ll}\begin{array}{l}\text { The bank as a } \\ \text { great place to }\end{array} & \begin{array}{l}\text { Diary: I don't think it's always } \\ \text { supportive for when you've got } \\ \text { issues and it doesn't get dealt with. } \\ \text { work }\end{array} \\ \text {. .our support structure is not what }\end{array}$

Diary: It was great

Diary: Yes, I feel

Diary: The new

more positive, I strategy [the

believe with staff merger] can work

input,

from well and they are

management, we performing at

can make a $\quad$ great levels.

difference.

difficult for me to say what

find solutions for

all issues that we

discussed.

Interview: If there's a walk in client that's probably maybe had an issue with another bank, our criteria,

then we right here. So for business centre, definitely I mean it's got the advantages.

Interview: You know when we're ere [in the branch] and we're visible to our clients so and to the branch staff...I can help them now or they can help me.

Diary: It is a great place to work,

leadership care

and want to make

a difference for

staff and clients.
Interview: It was also great to hear that there's people that have got great things to say about the bank, great things to their future in the bank, so it made me realise that you know...it's great.

Interview: I rate my job satisfaction as 'Good'. what would be a great

place to work. 
Representative Quotations

nterview: So sometimes you just need to reflect back and say, you know there's a lot of good things going as well.

Interview: It was nice to just be with people, or a bigger percentage of people that sees things

differently and more positively.

$\begin{array}{ll}\begin{array}{l}\text { The bank as } \\ \text { caring about }\end{array} & \begin{array}{l}\text { Diary following Design workshop: } \\ \text { employee }\end{array} \\ \begin{array}{l}\text { Poor decisions are made at the top } \\ \text { opinions }\end{array} & \begin{array}{l}\text { without input from the staff. This } \\ \text { workshop should have been held } \\ \text { before the change [merger]. }\end{array}\end{array}$

Diary: This is the first

workshop regarding the alignment that I had an opportunity to give an opinion.
Diary: I think it is great that we have the opportunity to discuss issues in the organisation.
Diary: It is great that they invest in focus groups like this one to get the staff input...t is clear that they care about the staff.
Diary: I am

ositive that ou leadership team cares what we think and what they can do to make it better.

Interview: They care enough about getting the results to see how they can do it differently or what must be looked at, what's really serious issues, burning issues, so that's quite positive to think that the team up there, they're interested and they want to know what went wrong.

Interview: If the bank takes the time and the money that they spend on the thing [the intervention] it also gives you the impression that they want to change.

Interview: I think everybody's so happy that somebody's taking notice of our problems and our issues.

Learning
regarding the
ability to choose
how to react to
change

Diary: I learnt to

concentrate on positive ideas, positive mind set.
Diary: Change starts with you. Try and focus on the positives. Share good stories, positive feedback with the team.
Diary: I intend to...embrace change and not always look at the negatives but focus on the positives.

Researcher: A change happened, let's take the alignment...Do you think, if you take a positive attitude, you see that change differently?

Susan: Definitely yes. 
Researcher: But it's the same change, the same thing has physically happened.

Susan: No, it's just depending how you see it in your mind.

Researcher: OK. So you can create your own reality, would you say?

Susan: I don't think I can create my own reality, but I think I can

definitely be creative with how I'm going to take that information.

Researcher: Did you see it [working in a branch] as important before?

Susan: No, I didn't want to see

\section{Learning to look}

at the bigger

picture of

organisational

change 
Table 3

Transition themes for the types of cognitive outcome patterns

\begin{tabular}{ll}
\hline $\begin{array}{l}\text { Type of } \\
\text { Transition }\end{array}$ & Definition \\
\hline $\begin{array}{l}\text { Changes in the } \\
\text { content of } \\
\text { schemata }\end{array}$ & $\begin{array}{l}\text { As drawn from Kegan (2000), where } \\
\text { new content is brought into the } \\
\text { existing schemata but there is no } \\
\text { change in subject-object balance in } \\
\text { the schemata. }\end{array}$ \\
\hline
\end{tabular}

\section{Transition Themes}

- The bank as caring about employee opinions.

- The bank as a great place to work.

- Learning about the impact of the merger on subordinates.

- Opinion of the merger.

- Learning to look at the bigger picture of organisational change.

- Learning about the need for participation in organisational change.

\begin{abstract}
Changes in the form of schemata

As drawn from Kegan (2000), where something which was subject in an individual's schemata now becomes object - where previously the individual was 'had by it' (captive of it) to where the individual 'has it' and can be in a relationship to it.
\end{abstract}

Development of an appreciative stance
- Learning regarding the ability to choose how to react to change.

- Assertiveness towards those more senior in the management hierarchy.

- Putting the change behind him/her.
Development of an appreciative stance is defined as striving to see something positively without a change in subject-object relations
- Positive attitude towards an organisationalchange out there. 
Table 4

Transitions per case

Transition in terms of:

\begin{tabular}{|c|c|c|c|c|c|c|c|c|c|}
\hline \multicolumn{6}{|c|}{ Changes in the content of schemata } & \multicolumn{3}{|c|}{ Changes in the form of schemata } & \multirow{2}{*}{$\begin{array}{c}\begin{array}{c}\text { Development } \\
\text { of an } \\
\text { appreciative } \\
\text { stance }\end{array} \\
\begin{array}{c}\text { Positive } \\
\text { attitude } \\
\text { towards an }\end{array} \\
\text { organisational- } \\
\text { change out } \\
\text { there }\end{array}$} \\
\hline $\begin{array}{l}\text { The bank } \\
\text { as caring } \\
\text { about } \\
\text { employee } \\
\text { opinions }\end{array}$ & $\begin{array}{c}\text { The } \\
\text { bank as } \\
\text { a great } \\
\text { place to } \\
\text { work }\end{array}$ & $\begin{array}{l}\text { Learning } \\
\text { about the } \\
\text { need for } \\
\text { participation } \\
\text { in org. } \\
\text { change }\end{array}$ & $\begin{array}{l}\text { Learning } \\
\text { about the } \\
\text { impact of the } \\
\text { merger on } \\
\text { subordinates }\end{array}$ & $\begin{array}{c}\text { Opinion } \\
\text { of the } \\
\text { merger }\end{array}$ & $\begin{array}{c}\text { Learning } \\
\text { to look } \\
\text { at the } \\
\text { bigger } \\
\text { picture } \\
\text { of org. } \\
\text { change }\end{array}$ & $\begin{array}{c}\text { Assertive } \\
\text { towards } \\
\text { those } \\
\text { more } \\
\text { senior in } \\
\text { the } \\
\text { mgmt.. } \\
\text { hierarchy }\end{array}$ & $\begin{array}{l}\text { Putting } \\
\text { the } \\
\text { alignment } \\
\text { behind } \\
\text { him/her }\end{array}$ & $\begin{array}{c}\text { Learning } \\
\text { regarding } \\
\text { the } \\
\text { ability to } \\
\text { choose } \\
\text { how to } \\
\text { react to } \\
\text { change }\end{array}$ & \\
\hline+ & + & 0 & + & 0 & + & + & + & 0 & + \\
\hline+ & + & 0 & 0 & + & + & 0 & 0 & + & 0 \\
\hline+ & + & 0 & 0 & + & + & 0 & 0 & 0 & + \\
\hline+ & 0 & + & 0 & 0 & 0 & 0 & 0 & 0 & + \\
\hline+ & 0 & 0 & 0 & 0 & 0 & 0 & 0 & 0 & + \\
\hline 0 & - & 0 & + & - & 0 & 0 & 0 & 0 & 0 \\
\hline
\end{tabular}

Notes: $\quad+\quad$ Transition in line with the intervention change objective

$0 \quad$ No transition

- Transition in opposite direction to the intervention change objective 
Table 5

Representative quotations for the influential characteristics of the intervention for each of Susan's

transition themes

Transition theme

Representative Quotations

Influential Characteristic(s) of the Intervention

Opinion of the merger So it was small things. Small things that you listened

Becoming aware of the viewpoints of others

to in the group and heard in the group that made

you think "You know what it's not that bad".

The bank as a great place
to work

It was also great to hear that there's people that have got great things to say about the bank, great things to their future in the bank, so it made me realise that you know...it's great.

It was nice to just be with people, or a bigger percentage of people that sees things differently and more positively.
The bank as caring about
employee opinions
If the bank takes the time and the money that they spend on the thing [the intervention] it also gives you the impression that they want to change.

Diary: It is great that they invest in focus groups like this one to get the staff input...It is clear that they care about the staff.
Learning regarding the ability to choose how to react to change
Researcher: Do you think your understanding or your appreciation of the effect of being positive...changed as a result of the Appreciative Inquiry?

Susan: Definitely, and I think once again...if you've got a whole bunch of people that's miserable and moaning and...You're going to become miserable as well and you have to somehow...and it was just nice to be with people that wasn't miserable all the time.

Researcher: Ok. There were some videos about being positive as well. Did that have an influence or was it really more than you were...?

Susan: I think it was more...it was definitely more the crowd, the people, the...

I mean wouldn't it be unfair if I sit here with my negative attitude and they [senior management] trying their best to change things? That wouldn't be fair.

She's [the facilitator] very positive...so I think she played quite a big role as well.
The fact that top management initiated an appreciative inquiry process
Becoming aware of the viewpoints of others
Becoming aware of the viewpoints of others
The fact that top management initiated an appreciative inquiry process.

The positive attitude of the facilitator. 
Table 6 Intervention characteristics for the transition themes

\begin{tabular}{|c|c|c|c|c|c|c|c|c|c|c|}
\hline & \multicolumn{10}{|c|}{ Transition in terms of: } \\
\hline & \multicolumn{6}{|c|}{ Changes in the content of schemata } & \multicolumn{3}{|c|}{ Changes in the form of schemata } & \multirow{2}{*}{$\begin{array}{l}\begin{array}{l}\text { Development of an } \\
\text { appreciative stance }\end{array} \\
\begin{array}{l}\text { Positive attitude } \\
\text { towards an } \\
\text { organisational-change } \\
\text { out there }\end{array}\end{array}$} \\
\hline & $\begin{array}{l}\text { Bank as caring } \\
\text { about } \\
\text { employee } \\
\text { opinions }\end{array}$ & $\begin{array}{l}\text { Bank as a } \\
\text { great place to } \\
\text { work }\end{array}$ & $\begin{array}{l}\text { importance of } \\
\text { participation } \\
\text { in an } \\
\text { organisational } \\
\text { change }\end{array}$ & $\begin{array}{l}\text { Learning } \\
\text { about the } \\
\text { impact of the } \\
\text { merger on } \\
\text { subordinates }\end{array}$ & $\begin{array}{l}\text { Opinion } \\
\text { of the } \\
\text { merger }\end{array}$ & $\begin{array}{l}\text { Learnt to look } \\
\text { at bigger } \\
\text { picture of org. } \\
\text { change }\end{array}$ & $\begin{array}{l}\text { Assertive } \\
\text { towards those } \\
\text { above }\end{array}$ & $\begin{array}{l}\text { Putting the } \\
\text { change behind } \\
\text { him/her }\end{array}$ & $\begin{array}{l}\text { Learnt can choose } \\
\text { how to react to } \\
\text { change }\end{array}$ & \\
\hline $\begin{array}{l}\text { Case: Lala } \\
\text { Intervention } \\
\text { characteristic(s) }\end{array}$ & $\begin{array}{l}\text { Top } \\
\text { management } \\
\text { initiating an } \\
\text { appreciative } \\
\text { inquiry process }\end{array}$ & $\begin{array}{l}\text { The } \\
\text { unconstrained } \\
\text { and holistic } \\
\text { nature of the } \\
\text { change } \\
\text { process }\end{array}$ & & $\begin{array}{l}\text { An } \\
\text { environment } \\
\text { in which } \\
\text { participants } \\
\text { felt free to } \\
\text { talk openly }\end{array}$ & & $\begin{array}{l}\text { The } \\
\text { unconstrained } \\
\text { and holistic } \\
\text { nature of the } \\
\text { change process }\end{array}$ & $\begin{array}{l}\text { An environment } \\
\text { in which } \\
\text { participants felt } \\
\text { free to talk } \\
\text { openly }\end{array}$ & $\begin{array}{l}\text { An environment } \\
\text { in which } \\
\text { participants felt } \\
\text { free to talk } \\
\text { openly }\end{array}$ & & Focusing on solutions \\
\hline & & $\begin{array}{l}\text { Becoming } \\
\text { aware of the } \\
\text { viewpoints of } \\
\text { others }\end{array}$ & & & & & & & & \\
\hline $\begin{array}{l}\text { Case: Susan } \\
\text { Intervention } \\
\text { characteristic(s) }\end{array}$ & $\begin{array}{l}\text { Top } \\
\text { management } \\
\text { initiating an } \\
\text { appreciative } \\
\text { inquiry process }\end{array}$ & $\begin{array}{l}\text { Becoming } \\
\text { aware of the } \\
\text { viewpoints of } \\
\text { others }\end{array}$ & & & $\begin{array}{l}\text { Becoming } \\
\text { aware of } \\
\text { the } \\
\text { viewpoints } \\
\text { of others }\end{array}$ & $\begin{array}{l}\text { Watching the } \\
\text { positive videos }\end{array}$ & & & $\begin{array}{l}\text { Becoming aware of } \\
\text { the viewpoints of } \\
\text { others } \\
\text { Top management } \\
\text { initiating an } \\
\text { appreciative } \\
\text { inquiry process } \\
\text { The positive } \\
\text { attitude of the } \\
\text { facilitator }\end{array}$ & \\
\hline $\begin{array}{l}\text { Case: Maria } \\
\text { Intervention } \\
\text { characteristic(s) }\end{array}$ & $\begin{array}{l}\text { Top } \\
\text { management } \\
\text { initiating an } \\
\text { appreciative } \\
\text { inquiry process }\end{array}$ & $\begin{array}{l}\text { Becoming } \\
\text { aware of the } \\
\text { viewpoints of } \\
\text { others }\end{array}$ & & & $\begin{array}{l}\text { Becoming } \\
\text { aware of } \\
\text { the } \\
\text { viewpoints } \\
\text { of others }\end{array}$ & $\begin{array}{l}\text { Becoming } \\
\text { aware of the } \\
\text { viewpoints of } \\
\text { others }\end{array}$ & & & & $\begin{array}{l}\text { The envisioning a positive } \\
\text { future activity }\end{array}$ \\
\hline
\end{tabular}




\begin{tabular}{|c|c|c|c|c|c|c|c|c|c|c|}
\hline & \multicolumn{10}{|c|}{ Transition in terms of: } \\
\hline & \multicolumn{6}{|c|}{ Changes in the content of schemata } & \multicolumn{3}{|c|}{ Changes in the form of schemata } & \multirow{2}{*}{\begin{tabular}{|l|}
$\begin{array}{l}\text { Development of an } \\
\text { appreciative stance }\end{array}$ \\
$\begin{array}{l}\text { Positive attitude } \\
\text { towards an } \\
\text { organisational-change } \\
\text { out there }\end{array}$ \\
\end{tabular}} \\
\hline & $\begin{array}{l}\text { Bank as caring } \\
\text { about } \\
\text { employee } \\
\text { opinions }\end{array}$ & $\begin{array}{l}\text { Bank as a } \\
\text { great place to } \\
\text { work }\end{array}$ & $\begin{array}{l}\text { importance of } \\
\text { participation } \\
\text { in an } \\
\text { organisational } \\
\text { change }\end{array}$ & $\begin{array}{l}\text { Learning } \\
\text { about the } \\
\text { impact of the } \\
\text { merger on } \\
\text { subordinates }\end{array}$ & $\begin{array}{l}\text { Opinion } \\
\text { of the } \\
\text { merger }\end{array}$ & $\begin{array}{l}\text { Learnt to look } \\
\text { at bigger } \\
\text { picture of org. } \\
\text { change }\end{array}$ & $\begin{array}{l}\text { Assertive } \\
\text { towards those } \\
\text { above }\end{array}$ & $\begin{array}{l}\text { Putting the } \\
\text { alignment } \\
\text { behind him/her }\end{array}$ & $\begin{array}{l}\text { Learnt can choose } \\
\text { how to react to } \\
\text { change }\end{array}$ & \\
\hline $\begin{array}{l}\text { Case: Allison } \\
\text { Intervention } \\
\text { characteristic(s) }\end{array}$ & $\begin{array}{l}\text { Top } \\
\text { management } \\
\text { initiating an } \\
\text { appreciative } \\
\text { inquiry process }\end{array}$ & & $\begin{array}{l}\text { the content of } \\
\text { the change } \\
\text { process was } \\
\text { determined by } \\
\text { the } \\
\text { participants }\end{array}$ & & & & & & & $\begin{array}{l}\text { The envisioning a } \\
\text { positive future activity } \\
\text { Watching the positive } \\
\text { videos }\end{array}$ \\
\hline $\begin{array}{l}\text { Case: Eddie } \\
\text { Intervention } \\
\text { characteristic(s) }\end{array}$ & $\begin{array}{l}\text { Top } \\
\text { management } \\
\text { initiating an } \\
\text { appreciative } \\
\text { inquiry process } \\
\end{array}$ & & & & & & & & & $\begin{array}{l}\text { Becoming aware of the } \\
\text { viewpoints of others } \\
\text { Watching the positive } \\
\text { videos }\end{array}$ \\
\hline $\begin{array}{l}\text { Case: Bernice } \\
\text { Intervention } \\
\text { characteristic(s) }\end{array}$ & & $\begin{array}{l}\text { The } \\
\text { envisioning a } \\
\text { positive } \\
\text { future } \\
\text { activity* }\end{array}$ & & $\begin{array}{l}\text { Completing } \\
\text { the pre- } \\
\text { intervention } \\
\text { diary } \\
\text { response } \\
\text { form }\end{array}$ & $\begin{array}{l}\text { The envisio } \\
\text { a positive } \\
\text { activity* }\end{array}$ & & & & & \\
\hline
\end{tabular}

* Transition in the opposite direction to that initially intended by the intervention 
Table 7

Categories of intervention characteristics

\begin{tabular}{ll}
$\begin{array}{l}\text { Category of } \\
\text { intervention } \\
\text { characteristics }\end{array}$ & \multicolumn{1}{c}{ Definition } \\
\hline $\begin{array}{l}\text { Engaging emergent } \\
\text { change process }\end{array}$ & $\begin{array}{l}\text { A change process that encourages } \\
\text { participants to interact and talk freely in } \\
\text { order to determine the content of the } \\
\text { change process. }\end{array}$
\end{tabular}

Intervention characteristics

The fact that the content of the change process was determined by the participants.

The unconstrained and holistic nature of the change process.

An environment in which participants felt free to talk openly.

Becoming aware of the viewpoints of others.

Completing the pre-intervention diary response form.

The positive focus of As drawn from Cooperrider, Whitney the change process and Stavros (2008), a change process which is solution, not problem focused and which encourages attention to the best in people, their organisation, and the relevant world around them.

The fact that organizational leaders initiated an appreciative inquiry process
The envisioning a positive future activity

Watching the positive videos

Focusing on solutions.

The positive attitude of the facilitator.

That top management had initiated an appreciative inquiry process. 
Table 8

Intervention characteristic related to cognitve transitions

\begin{tabular}{|c|c|c|c|c|c|}
\hline \multirow{3}{*}{$\begin{array}{l}\text { Intervention } \\
\text { characteristic } \\
\text { categories }\end{array}$} & \multicolumn{4}{|c|}{ Transition } & \multirow{3}{*}{$\begin{array}{l}\text { Total number of } \\
\text { times an } \\
\text { intervention } \\
\text { characteristic } \\
\text { category was } \\
\text { associated with } \\
\text { an instance of } \\
\text { transition }\end{array}$} \\
\hline & $\begin{array}{l}\text { Changes in } \\
\text { (and in line with initia }\end{array}$ & (and in line with initial objective of the intervention) & \multirow{2}{*}{$\begin{array}{l}\text { Changes in } \\
\text { the form of } \\
\text { schemata }\end{array}$} & \multirow{2}{*}{$\begin{array}{l}\text { Development of } \\
\text { an appreciative } \\
\text { stance }\end{array}$} & \\
\hline & $\begin{array}{l}\text { Bank as caring about } \\
\text { employee opinions }\end{array}$ & $\begin{array}{l}\text { Five other transition } \\
\text { themes }\end{array}$ & & & \\
\hline $\begin{array}{l}\text { Top } \\
\text { management } \\
\text { initiating an } \\
\text { appreciative } \\
\text { inquiry } \\
\text { process }\end{array}$ & 5 & & 1 & & 6 \\
\hline $\begin{array}{l}\text { Engaging, } \\
\text { emergent } \\
\text { change } \\
\text { process }\end{array}$ & & 11 & 3 & 1 & 15 \\
\hline $\begin{array}{l}\text { The positive } \\
\text { focus of the } \\
\text { change } \\
\text { process }\end{array}$ & & 1 & 1 & 5 & 7 \\
\hline
\end{tabular}

